\title{
Kinetic Performance of Ascorbic Acid Degradation on Local Lemon Juice using Different Packaging Materials at Storage
}

\author{
Rajab Ibrahim Hameed, Anwer N. Mamdoh
}

\begin{abstract}
Kinetic of ascorbic acid dissolution of vitamin ( $C$ ) in Lemon juice 10 Brix packaged in glass and plastic bottles stored at 20,30 and $40^{\circ} \mathrm{C}$ for four months have been investigated .The results showed that increasing temperature and period storage caused decreasing in ascorbic acid content and increasing nonenzymatic browning. The stability of ascorbic acid and reduced of nonenzymatic browning was better in the packed in glass bottles. The results of ascorbic acid degradation kinetic parameter showed that the order of the reaction is First and there was an increasing in rate constant(K)in the case of increasing of the storage temperature and in the samples of glass bottlesk.The activation energy (Ea) decrease in plastic bottles. It was found that the shelf life of samples decreased with increasing the storage temperature. We got in this study the shelf life of ascorbic acid from 0 to $50^{\circ} \mathrm{C}$.
\end{abstract}

Keywords: packaging, lemon, Ascorbic acid, Kinetic, Activation energy, Dissolution

\section{INTRODUCTION}

The packaging is one of the most significant factors of value-addition chain of activities in the food or agroprocessing business. The main purposes of packages are to receive, preserve and protect products during their shipping, warehousing, and handling. The packaging is further applied to give possible users as far as product usage and nutritional content is affected. Food is packaged to maintain its condition, freshness, and interest to purchasers and to help storehouse and shipping. For the majority of food goods, the protection provided by the package is considered as the principal purpose of the package and is a necessary part of the protection process.[1]

Lemon juice is the drunkest because of its refreshing flavor with a large content of vitamin C. The food and refreshments business is currently studying for proper raw elements and packaging to enhance the condition and shelf time of goods. Property and shelf time perception of a lemon juice is heavily based on vitamin $\mathrm{C}$ development throughout storehouse for example intensity and taste[2],[3]),[4].

Revised Manuscript Received on June 22, 2019.

Rajab Ibrahim Hameed, Duhok Polytechnic University, Duhok Technical Inistitute, dept. medical lab technology, Duhok .krd . Iraq

Anwer N. Mamdoh, Duhok Polytechnic University, Duhok Technical Institute, dept.Pharmacy, Duhok .krd . Iraq
Vitamin $\mathrm{C}$ is a crucial nutrient for individuals and because of its extraordinary antioxidant ability, it gives protection upon the behavior of free radicals engaging in the obstruction of various infections [5]. Lemon juice is packed in a broad variety of elements such as metal jars, paperboard cases, plastic boxes, and glass jars. When packaging elements do not present enough obstacle to light and oxygen, the quality of the juice can be altered. The most usual difficulties include browning of the juice is decline in ascorbic acid and differences in the taste of the juice. Businesses have discovered that applying unconventional packaging may improve selling. The circumstances concerning vitamin $\mathrm{C}$ decline in packed orange juice are temperature, decayed oxygen, and oxygen limitation granted by the package elements [2]. A new aim is to apply transparent containers for lure buyers with the fresh, radiant color of citrus juices. Glass is being applied, nevertheless, this element is costly, heavy, and prone to damage. to solve this problem is to use clear plastic [3],[8] proclaimed that light has no impact on ascorbic acid content and it's an unimportant influence on browning of orange juices stocked for 52 days at $8^{\circ} \mathrm{C}$. The determination of the packaging element for fruit juices is a critical detail concerning shelf development and various studies have been done on this matter. For the lemon juice, a plastic container is being utilized in a limited study [9]. Popular techniques were applied for juice packaging aiming to decrease the exposure of the juice to oxygen by using huge barrier elements like glass or foil laminates in brick packs, including or not nitrogen flushing [10]. proclaimed that when lemon juice was saved for five months at $22^{\circ} \mathrm{C}$, They discovered that elevated measures of oxygen in the juice led to increased browning and that ascorbic acid declines were $60.6 \%, 54.6 \%, 51.0 \%$, and $45.5 \%$ in clear glass, Tetrapak layered paper, and amber glass sequentially, when the containers of lemon juice stored at room temperature for 32 days.[4] reported that when the lemon juice was stored at 25,35 and $45 \mathrm{oC}$ for four months the ascorbic acid lost increase with increasing the temperatures and the time of storage and show that the temperature coefficient increase from 1.568 times when the temperature of storage rise from 25 to $350 \mathrm{c}$, while increase 2.771 times when the temperature of storage rise from $35-45$ oC. This study investigated the influence of temperature and packaging elements on the Vitamin (C) dissociation of lemon juice during storage, and to determine the shelf-life and nonenzymatic browning. 


\section{MATERIAL AND METHODS}

\section{Sample preparation}

Fresh lemon (citrus lemon var local) of approximately equal in size and weight. The products were carried to the chemical laboratories at Duhok technical institute. They were cleaned and sliced in two halves and hand-squeezed for juice. The Juice description was conducted by a regular kitchen filter. Then pasteurized at $82^{\circ} \mathrm{C}$ for $15 \mathrm{~s}$ and while still hot filled into glass bottles and plastic bottles with capacity $130 \mathrm{ml}$ leaving a headspace of about $10 \%$.The juice divided to two groups as glass bottles and plastic bottles .All samples stored at 20,30 and $40^{\circ} \mathrm{C}$ for four months.

B. Vitamin C.Aascorbic acid concentration was measured for each month by the 2,6-dichlorophenol indophenol according to the approach of[5], each specimen was provided and examined in triplicate.

C.Nonenzymatic browning. .Absorbance measurement at $420 \mathrm{~nm}$ was performed with spectrophotometer(TRSP-721) according to [6]

D.Kinetic degradation of Vitamin C.

for each month rate constant for ascorbic acid degradation were calculated through linear regression analysis of $\operatorname{Ln}[\mathrm{A}]$ analog storage time [6].

Half time(t1/2)was calculate according to the equation which said by [2].

\section{$\mathrm{T} 1 / 2=\mathrm{Ln}(2) / \mathrm{K}$.}

$\mathrm{K}=$ constant.

Activation energy(Ea)was calculate according to the equation which said [2].

Slope $=\mathrm{Ea} /(2.303 * \mathrm{R})$.

$\mathrm{R}($ gas constant $)=1.987$ cal -1 .mol.

Slope and intercept calculate from the Arrhenius plots shown in figure (1), [6] using Microsoft Excel 2007.

Shelf life calculate according to the equation observed by[4]

Expire $=\mathrm{e}-(\mathrm{s} / \mathrm{T}+\mathrm{I}-\operatorname{Ln}(-\operatorname{Ln}) \mathrm{p} / 100)))$.

$\mathrm{S}=$ slope, $\mathrm{T}=$ kelven temperature, $\mathrm{I}=$ intercept, $\mathrm{P}=$ residual (AA)

Statistically analysis.

Data were statistically analyzed with SPSS 2003, and the means verifying were done according to Duncan's multiple range test at level $1 \%$.

\section{RESULTS AND DISCUSSION}

\section{Nonenzymatic browning (NEB).}

(Nonenzymatic browning (NEB)) development in samples was determined soluble brown pigments as (absorbance at $420 \mathrm{~nm}$. Changes in $\mathrm{A}_{420}$ values for lemon juice during storage for four months at 20,30 and $40^{\circ} \mathrm{C}$ are shown in table 1 .The browning color increase with increasing the storage time and increasing temperature of storage. The results in the same table are apparent that samples which stored in plastic bottles contain more concentration of browning pigments than samples stored in the glass bottles ,because plastic allows more oxygen permeation .Statistical analysis showed that temperature and different packaging materials had significant effect( $\mathrm{p}<0.01)$ on color samples. This results agrees with other researchers such as[7],[6].

Table. 1 Brown index (Absorbance at $420 \mathrm{~nm}$ ) of lemon juice stored in various conditions•

\begin{tabular}{|c|c|c|c|c|c|}
\hline \multirow{2}{*}{$\begin{array}{l}\text { packaging } \\
\text { materials }\end{array}$} & \multirow{2}{*}{$\begin{array}{l}\text { Tempe } \\
\text { rature } \\
{ }^{0} \mathrm{C}\end{array}$} & \multicolumn{4}{|c|}{ Storage time (month) } \\
\hline & & 1 & 2 & 3 & 4 \\
\hline \multirow[t]{3}{*}{$\begin{array}{l}\text { Glass } \\
\text { bottle }\end{array}$} & 20 & $\begin{array}{l}0.02 \\
\mathrm{~A} \mathrm{a}\end{array}$ & $\begin{array}{l}0.09 \\
\mathrm{Ba}\end{array}$ & $\begin{array}{l}0.13 \\
\mathrm{Ca}\end{array}$ & $\begin{array}{l}0.15 \\
\mathrm{Da}\end{array}$ \\
\hline & 30 & $\begin{array}{l}0.11 \\
\mathrm{Ab}\end{array}$ & $\begin{array}{l}0.15 \\
\mathrm{Bb}\end{array}$ & $\begin{array}{l}0.19 \\
\mathrm{Cb}\end{array}$ & $\begin{array}{l}0.23 \\
\mathrm{Db}\end{array}$ \\
\hline & 40 & $\begin{array}{l}0.20 \\
\text { A c }\end{array}$ & $\begin{array}{l}0.24 \\
\mathrm{Bc}\end{array}$ & $\begin{array}{l}0.32 \\
\mathrm{Cd}\end{array}$ & $\begin{array}{l}0.34 \\
\mathrm{Dc}\end{array}$ \\
\hline \multirow[t]{3}{*}{$\begin{array}{l}\text { Plastic } \\
\text { bottle }\end{array}$} & 20 & $\begin{array}{l}0.13 \\
\mathrm{Ab}\end{array}$ & $\begin{array}{l}0.15 \\
\mathrm{Bb}\end{array}$ & $\begin{array}{l}0.18 \\
\mathrm{Cb}\end{array}$ & $\begin{array}{l}0.22 \\
\mathrm{Db}\end{array}$ \\
\hline & 30 & $\begin{array}{l}0.18 \\
\text { Ac }\end{array}$ & $\begin{array}{l}0.22 \\
\mathrm{Bc}\end{array}$ & $\begin{array}{l}0.25 \\
\mathrm{Cc}\end{array}$ & $\begin{array}{l}0.32 \\
\text { Dc }\end{array}$ \\
\hline & 40 & $\begin{array}{l}0.23 \\
\mathrm{Ad}\end{array}$ & $\begin{array}{l}0.28 \\
\mathrm{Bd}\end{array}$ & $\begin{array}{l}0.33 \\
\mathrm{Cd}\end{array}$ & $\begin{array}{l}0.40 \\
\mathrm{Dd}\end{array}$ \\
\hline
\end{tabular}

Different capital letters in row means the values differ significantly $\mathrm{p}<0.01$ according to Duncan as a result of period storage.

Different small letters in column means the values differ significantly $\mathrm{p}<0.01$ according to Duncan as a result of packaging and temperature of storage.

Initial concentration of AA is $43 \mathrm{mg} / 100 \mathrm{ml}$

\section{Ascorbic acid content}

Table 2 and fig 2 show content of ascorbic acid in lemon juice reserved at $20,30,40{ }^{\circ} \mathrm{C}$ for four months. It was apparent that units that were reserved in plastic containers dropped further ascorbic acid than saved in glass container, because plastic allows more oxygen permeation...The results can be seen in the same table illustrate that a rise in storage temperature and time caused an increase in loss of ascorbic acid. The treatment which presented the best retention of ascorbic acid was packed glass bottles stored at $20^{\circ} \mathrm{C}$. This results agrees with other authors as [6],[8] and[9].Also there are increasing loss of ascorbic acid in samples stored in plastic bottle and thus due to allowing more oxygen permeation which is consistent with finding by [4]. 
Table. 2 ascorbic acid content $(\mathrm{mg} / 100 \mathrm{ml})$ in lemon juice in different temperatures at storage ${ }^{\bullet}$

\begin{tabular}{|l|l|l|l|l|l|}
\hline \multirow{2}{*}{$\begin{array}{l}\text { packagin } \\
\text { g }\end{array}$} & \multirow{2}{*}{$\begin{array}{l}\text { Tem } \\
\text { mera } \\
\text { ture } \\
\end{array}$} & \multicolumn{4}{|l|}{ Storage time (month) } \\
\cline { 2 - 6 } & ${ }^{\mathbf{C}} \mathrm{C}$ & 1 & 2 & 3 & 4 \\
\hline \multirow{2}{*}{$\begin{array}{l}\text { Glass } \\
\text { bottle }\end{array}$} & 20 & $32 \mathrm{~A} \mathrm{a}$ & $29 \mathrm{Ba}$ & $27 \mathrm{Ba}$ & $25 \mathrm{Ca}$ \\
\cline { 2 - 6 } & 30 & $\begin{array}{c}26 \mathrm{~A} \\
\mathrm{~b}\end{array}$ & $23 \mathrm{Bb}$ & $20 \mathrm{Cb}$ & $18 \mathrm{Cb}$ \\
\cline { 2 - 6 } & 40 & $17 \mathrm{Ac}$ & $14 \mathrm{Bc}$ & $10 \mathrm{Cc}$ & $6 \mathrm{Dd}$ \\
\hline \multirow{3}{*}{$\begin{array}{l}\text { Plastic } \\
\text { bottle }\end{array}$} & 20 & $25 \mathrm{Ab}$ & $22 \mathrm{Bb}$ & $18 \mathrm{Cb}$ & $16 \mathrm{Cb}$ \\
\cline { 2 - 6 } & 30 & $16 \mathrm{Ac}$ & $\begin{array}{l}14 \\
\mathrm{ABc}\end{array}$ & $12 \mathrm{Bc}$ & $9 \mathrm{Cc}$ \\
\cline { 2 - 6 } & 40 & $10 \mathrm{Ad}$ & $6 \mathrm{Bd}$ & $2 \mathrm{Cd}$ & $0.3 \mathrm{Ce}$ \\
\hline
\end{tabular}

Different capital letters in row means the values differ significantly $\mathrm{p}<0.01$ according to Duncan as a result of period storage.

Different small letters in colum means the values differ significantly $\mathrm{p}<0.01$ according to Duncan as a result of packaging and temperature of storage.

Initial concentration of AA is $33 \mathrm{mg} / 100 \mathrm{ml}$

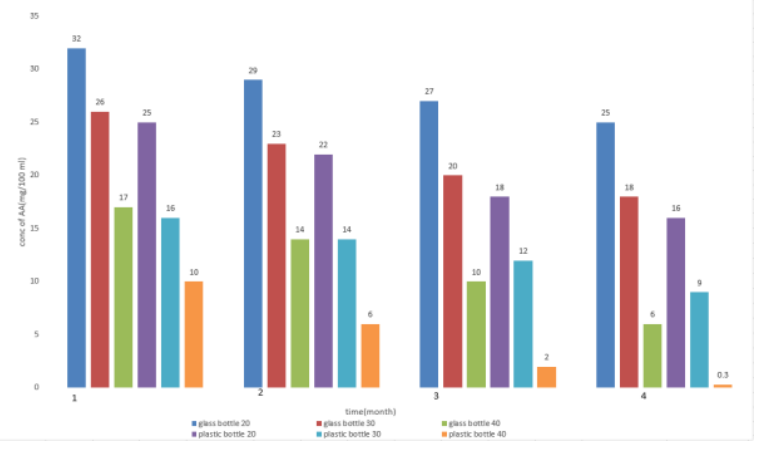

Fig. 1 ascorbic acid content in lemon juice in different temperatures at storage

\section{Kinetic dissolution of ascorbic acid}

The structure of development in Ln of ascorbic acid degradation with a time of storage allowed continuous lines (fig3). Therefore, the degradation of ascorbic acid in this research was characterized by a first -order reaction. The first order dynamic design for ascorbic acid degradation prepared in this research is in conjunction with different studies for other researchers[4] The rate constant(K)for ascorbic acid degradation were different at low and high temperatures for the same samples(table 2).The results indicated that the rate constant $(\mathrm{K})$ of ascorbic acid loss was higher at elevated temperatures, because the rise in temperature, increases the reaction rate of ascorbic acid loss. Also, the results in the same table indicated that the rate constant different with different packaging material $\left(0.0725 \mathrm{month}^{-1}\right.$ in glass bottles stored in $20^{\circ} \mathrm{C}$ and 0.1776 month $^{-1}$ in plastic bottles stored in same temperature) because the plastic bottles has oxygen permeability which increase the degradation of ascorbic acid. Also we saw in the same table the half time $t_{1 / 2}$ (the time requisite to react half of initial concentration of substrate) of ascorbic acid loss decrease with increasing the temperature of storage, the results were 9.561,4.699 and 1.760 months for glass bottles stored at 20,30 and $40{ }^{\circ} \mathrm{C}$ respectively. The results in the same table indicated that the half time of the samples stored in plastic bottle lower than samples stored in glass bottle at the same temperatures $(3.903,2.412$ and 0.630 months for plastic bottle stored at 20,30 and $40{ }^{\circ} \mathrm{C}$ respectively. This results agree with other studies [10]who found much better retention of ascorbic acid in stored orange juice at $4^{\circ} \mathrm{C}$ compared to those at $25^{\circ} \mathrm{C}$. The activation energy value (Ea)for ascorbic acid destruction(table 3), show the values of activation energy(Ea) of ascorbic acid degradation of samples stored in glass bottles was lower than samples stored in plastic bottles. The( Ea )value of ascorbic acid degradation samples for glass bottles was 35.53268 k.cal.mol ${ }^{-1}$,while for plastic bottles was 38.16743 k.cal.mol ${ }^{1}$.This results indicate that the material which presented the best retention of ascorbic acid was glass bottles comparison to plastic bottles. The plastic bottles presented a poor retention of ascorbic acid. Oxygen one of main factors that contributes to ascorbic acid degradation. Results indicate that glass was the material that presents the lowest oxygen permeability comparison to plastic. This results agrees with other researchers [10] [11]

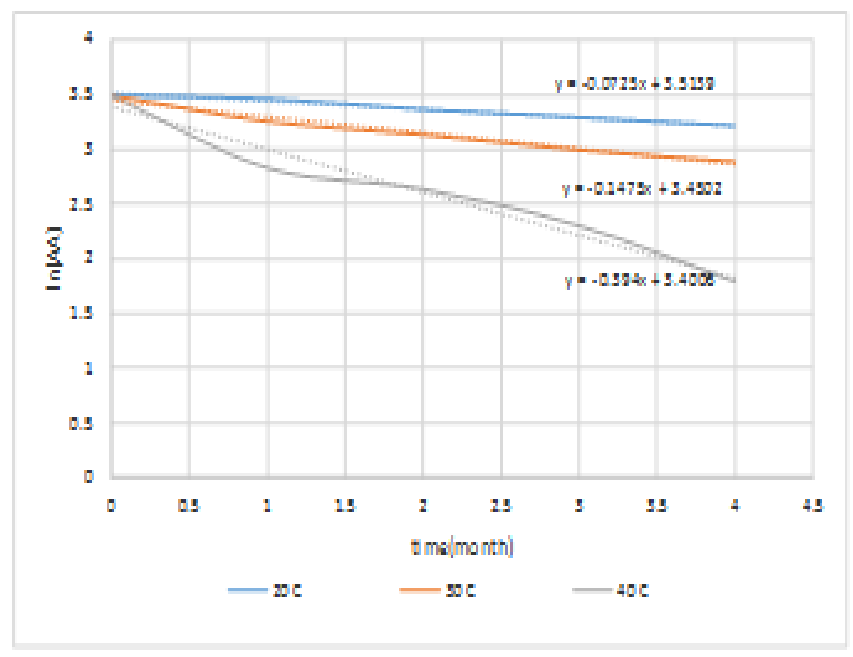

(A

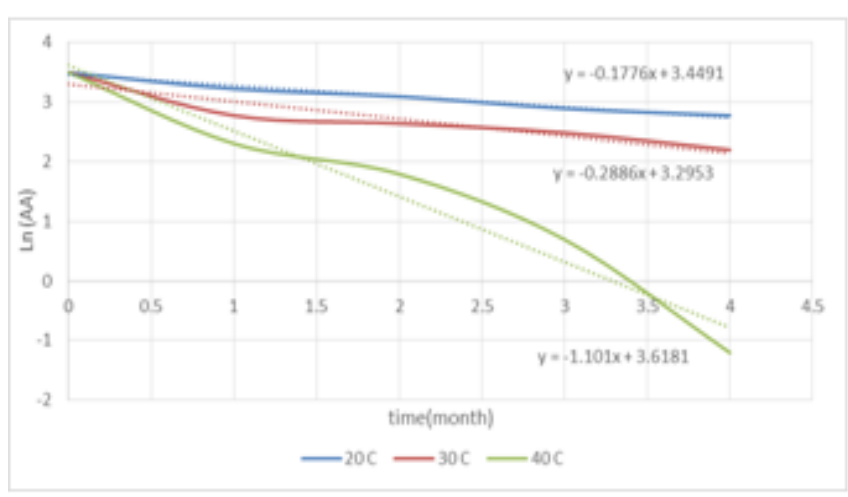

(B)

Published By: 
Kinetic Performance of Ascorbic Acid Degradation on Local Lemon Juice using Different Packaging Materials at Storage

Fig. 2 The relation between $L n$ of ascorbic acid degradation and time:(A)glass bottle.(B)plastic bottle

Table. 3 Rate constant $(K)$, half $\operatorname{timr}\left(t_{1 / 2}\right)$ and activation energy(Ea) of ascorbic acid degradation for lemon juice at different temperatures an different Packaging materials at storage

Correlation coefficient (R2). Relationships between two variables ( $\mathrm{x}$ and $\mathrm{y}$ ).

Is a change in one of these variables associated with a change in the other? (R2) was calculated from the straight line of the relationship between Ln of the rate constant $(\mathrm{K})$ and inverted of absolute temperature (1/T K) (Fig3).

We saw in table(4) the correlation confident is 0.9876 for glass bottle and 0.9221 for plastic bottle this indicate that there is a strong relationship between the two variable temperature and storage time for degradation of ascorbic acid in lemon juice at storage. This results agree with other studies[2],[9] .In the same table we saw the temperature coefficient(Q10) is 2.035 when the storage temperature rise from 20-30 $0 \mathrm{C}$ and 2.67 when the storage temperature rise from 30-40 0C for the samples stored in glass bottle while

Table. 4 Correlation coefficient and Temperature coefficient of degradation of vitamin $c$ in lemon juice when the samples stored in plastic bottle the temperature confident was 2.247 when the temperature of storage rise from 20-30 0C and 3.814 when the temperature of storage rise from 30-40 $0 \mathrm{C}$, that mean in increasing the temperature the molecule of ascorbic acid take more of heat energy and increase degradation of ascorbic acid, These above results are also within the range of values reported by [12],[13]

\begin{tabular}{|c|c|c|c|c|}
\hline $\begin{array}{l}\text { Packagin } \\
\mathrm{g} \\
\text { materials }\end{array}$ & $\begin{array}{l}\text { Temperatur } \\
\mathrm{e}^{\circ} \mathrm{C}\end{array}$ & $\begin{array}{l}\text { Rate } \\
\text { constant( } \\
\text { K) month } \\
1\end{array}$ & $\begin{array}{l}\text { Half } \\
\text { time }\left(\mathrm{t}_{1 / 2}\right. \\
\text { ) month }\end{array}$ & $\begin{array}{l}\text { Activatio } \\
\text { n } \\
\text { energy(E } \\
\text { a) } \\
\text { k.cal.mol } \\
1\end{array}$ \\
\hline \multirow{3}{*}{$\begin{array}{l}\text { Glass } \\
\text { bottle }\end{array}$} & 20 & 0.0725 & $\begin{array}{l}9.56065 \\
1\end{array}$ & \multirow[t]{3}{*}{35.53268} \\
\hline & 30 & 0.1475 & $\begin{array}{l}4.69930 \\
3\end{array}$ & \\
\hline & 40 & 0.394 & $\begin{array}{l}1.75925 \\
7\end{array}$ & \\
\hline \multirow{3}{*}{$\begin{array}{l}\text { Plastic } \\
\text { bottle }\end{array}$} & 20 & 0.1776 & $\begin{array}{l}3.90285 \\
6\end{array}$ & \multirow[t]{3}{*}{38.16743} \\
\hline & 30 & 0.2886 & $\begin{array}{l}2.40175 \\
7\end{array}$ & \\
\hline & 30 & 1.101 & $\begin{array}{l}0.62956 \\
1\end{array}$ & \\
\hline
\end{tabular}

\begin{tabular}{|c|c|c|c|c|}
\hline \multirow[t]{2}{*}{$\begin{array}{l}\text { Packaging } \\
\text { materials }\end{array}$} & \multirow[t]{2}{*}{ Temperature ${ }^{\circ} \mathrm{C}$} & \multirow[t]{2}{*}{$\begin{array}{l}\text { Correlation } \\
\text { coefficient }\left(\mathrm{R}^{2}\right)\end{array}$} & \multicolumn{2}{|c|}{$\begin{array}{l}\text { Temperature } \\
\text { coefficient }\left(\mathrm{Q}_{10}\right)\end{array}$} \\
\hline & & & $\begin{array}{l}20-30 \\
{ }^{0} \mathrm{C}\end{array}$ & $\begin{array}{l}30-40 \\
{ }^{0} \mathrm{C}\end{array}$ \\
\hline \multirow{3}{*}{$\begin{array}{l}\text { Glass } \\
\text { bottle }\end{array}$} & 20 & \multirow[t]{3}{*}{0.9876} & \multirow[t]{3}{*}{2.035} & \multirow[t]{3}{*}{2.67} \\
\hline & 30 & & & \\
\hline & 40 & & & \\
\hline \multirow{3}{*}{$\begin{array}{l}\text { Plastic } \\
\text { bottle }\end{array}$} & 20 & \multirow[t]{3}{*}{0.9221} & \multirow[t]{3}{*}{2.247} & \multirow[t]{3}{*}{3.814} \\
\hline & 30 & & & \\
\hline & 30 & & & \\
\hline
\end{tabular}

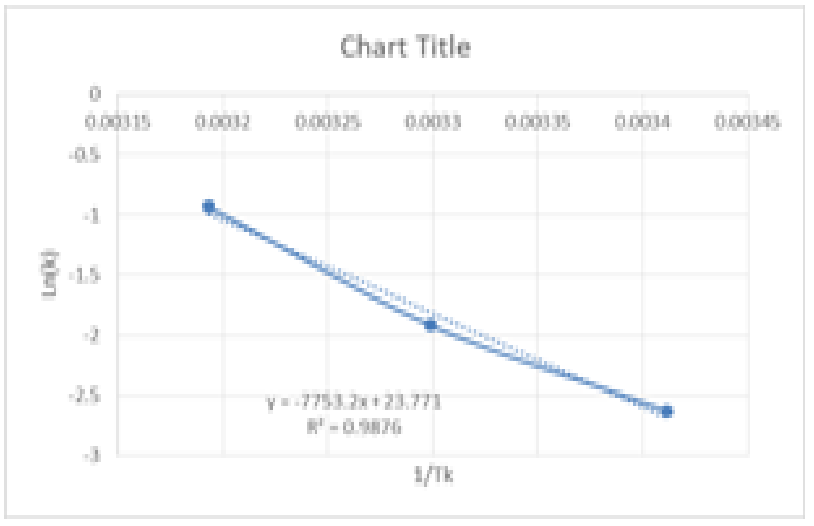

(A)

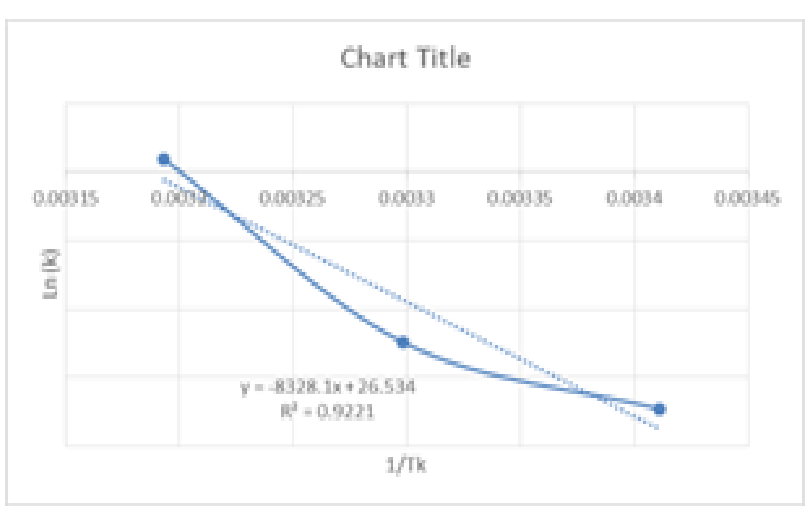

(B)

Fig 3.The relation between $\mathrm{Ln}$ of $\mathrm{K}$ and inverted of absolute temperature (1/T $\left.\mathrm{T}_{\mathrm{K}}\right)$ Angles bottle, $B$. plastic bottle 
Shelf-life considering the limit for shelf life to ascorbic acid degradation (table 5).Taking into account values from all treatment it is observed that glass bottles stored at $0{ }^{\circ} \mathrm{C}$ has a longer shelf life (25.20 months when the loss of ascorbic acid is $25 \%$ and 50.39 months when the loss of ascorbic acid is $50 \%$ ) while the shelf life of samples stored in plastic bottle is less in the same storage temperature and lost the same rate of ascorbic acid and we saw 13.65 months and 26.09 months for samples stored in plastic bottle at ${ }^{0} \mathrm{C}$. This mean the shelf life decreased with increasing the temperature of storage and the storage in glass bottle best than plastic bottle...This results agrees with other researchers as[14],[15],[16]

Table. 5 Shelf life of lemon juice according of ascorbic acid

\begin{tabular}{|c|c|c|c|c|}
\hline \multirow{3}{*}{ 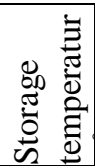 } & \multicolumn{4}{|c|}{ treatment } \\
\hline & \multicolumn{2}{|c|}{ Glass bottle } & \multicolumn{2}{|c|}{ Plastic battle } \\
\hline & \multicolumn{4}{|c|}{$\%$ lost of $\mathrm{AA}$} \\
\hline 25 & & 50 & 25 & 50 \\
\hline \multicolumn{5}{|c|}{ Shelf life(month) } \\
\hline \begin{tabular}{l|l}
0 &
\end{tabular} & 25.20 & 50.39 & 13.95 & 26.09 \\
\hline 5 & 15.13 & 30.26 & 7.54 & 15.08 \\
\hline 10 & 9.25 & 18.49 & 4.45 & 8.89 \\
\hline 15 & 5.75 & 11.50 & 2.67 & 5.34 \\
\hline 20 & 3.64 & 7.26 & 1.63 & 3.34 \\
\hline 25 & 2.33 & 4.67 & 1.01 & 2.02 \\
\hline 30 & 1.52 & 3.04 & 0.64 & 1.28 \\
\hline 35 & 1.10 & 2.01 & 0.41 & 0.82 \\
\hline 40 & 0.67 & 1.34 & 0.27 & 0.53 \\
\hline 45 & 0.45 & 0.91 & 0.17 & 0.35 \\
\hline 50 & 0.31 & 0.62 & 0.12 & 0.23 \\
\hline
\end{tabular}

\section{CONCLUSION}

The initial content of Ascorbic acid for lemon juices was $33 \mathrm{mg} / 100 \mathrm{ml}$. the browning index (Nonenzymatic browning for all samples increase with increasing the storage temperature and time. The concentrations of ascorbic acid or Vitamin $\mathrm{C}$ for in each specimen were reduced by time in storage house due to storage house temperature. The dissolution of vitamin $\mathrm{C}$ in all specimens of the juices was observed to follow first-order reaction kinetics.

The dissolution response rate constants were increased with increasing storage house temperature. They ranged $0.0725,0.1475$, and 0.394 for samples stored in glass bottle at 20,30 , and $40{ }^{\circ} \mathrm{C}$ respectively while there was 0.1776 , 0.2886 and 1.101 for samples stored in plastic bottle at 20 , 30 , and $40{ }^{\circ} \mathrm{C}$ respectively. The ascorbic acid content after 4 months was best in low temperature of storage and also the glass bottle is best for storage from plastic bottle.

The activation energy for the dissolution reaction of vitamin $\mathrm{C}$ in lemon juice was 35.53268 for samples in glass bottle while $38.16743 \mathrm{~K} . \mathrm{cal} / \mathrm{mol}$ for plastic bottle. The half time were decreased with increasing storage house temperature, and more in glass bottle than plastic bottle... The temperature coefficients $\left(\mathrm{Q}_{10}\right)$ was more in samples stored in plastic bottle than stored in glass bottle. The self- life of ascorbic acid decrease with increasing the temperatures of storage house and it was less in sample stored in plastic bottle than stored in glass bottle.

\section{REFERENCE}

1. S. K. Anin, W. O. Ellis, and J. Adubofuor, "Effects of two packaging materials and storage conditions on the quality of fresh taste , a natural and locally produced orange drink in Ghana," J. Food Sci., vol. 1, no. 6, pp. $132-138,2010$

2. C. D. Souza, H. Yuk, G. H. Khoo, and W. Zhou, "Application of LightEmitting Diodes in Food Production,Postharvest Preservation, and Microbiological Food Safety."

3. D. Raheem, "Application of plastics and paper as food packaging materials - An overview," vol. 25, no. 3, pp. 177-188, 2012.

4. M. M. I. Al-zubaidy and R. A. Khalil, "Food Chemistry Kinetic and prediction studies of ascorbic acid degradation in normal and concentrate local lemon juice during storage," vol. 101, pp. 254-259, 2007

5. N. Shrestha and A. Bhattarai, "Determination of Ascorbic Acid in Different Citrus Fruits of Kathmandu Valley," vol. 2, no. 1, pp. 9-14, 2016.

6. N. Koca, H. S. Burdurlu, and F. K. Z, "Kinetics of Nonenzymatic Browning Reaction in Citrus Juice Concentrates during Storage," vol. 27, pp. 353-360, 2003.

7. R. Sindhu and B. S. Khatkar, "Preservation and storage of Lemon ( Citrus Limon ) Juice,” vol. 6495, no. 3, pp. 154-158, 2018.

8. M. Hekkert, L. Joosten, and E. Worrell, "MATERIAL EFFICIENCY IMPROVEMENT FOR EUROPEAN PACKAGING IN THE PERIOD 2000 - 2020," no. 2050, 2020.

9. R. Sindhu and B. S. Khatkar, "Effects of Chemical Treatments on Storage Stability of Lemon ( Citrus Limon ) Juice,” pp. 76-79, 2018.

10. P. Packaging, "Plastic Packaging and Plastic Bottles Regulation SI 98 ,"pp. 11-14, 2017.

11. P. Ghose and P. Nair, "Packaging of Carbonated Beverages," vol. 4, no. 5, pp. 421-430, 2013.

12. L. M. Avallone, "Measurements of the temperature-dependent rate coefficient for the reaction O ( 3 P ) + NO $2 \rightarrow \mathrm{NO}+\mathrm{O} 2$," vol. 157 , no. 2, pp. 231-236, 2003.

13. X. Huang, L. Zhang, X. Wang, and D. Wu, "Determination of the Reaction Rate Constant for the Opposing Reaction by Integral Method," vol. 55, pp. 19-24, 2016.

14. B. Vikram, M. N. Ramesh, and S. G. Prapulla, "Thermal degradation kinetics of nutrients in orange juice heated by electromagnetic and conventional methods," J. Food Eng., vol. 69, no. 1, pp. 31-40, 2005.

15. E.F, E. E.O, K. A.M, and A. M.M, "Kinetic Modeling of Vitamin C (Ascorbic Acid) Degradation in Blanched Commonly Consumed Salad Vegetables Using Computer Simulation Analysis," IOSR J. Appl. Chem., vol. 10, no. 04, pp. 59-66, 2017.

16. C. Polydera, N. G. Stoforos, and P. S. Taoukis, "Comparative shelf life study and vitamin C loss kinetics in pasteurised and high pressure processed reconstituted orange juice," vol. 60, pp. 21-29, 2003. 